a method, it had the considerable advantage of showing her students the rewards that lay ahead of them in their study of this difficult language. In the hope of introducing a wider readership to Arabic literature, Dr. Lichtenstadter in 1972 assumed the general editorship of the Library of Classical Arabic Literature (Twayne Publishers, Inc.), a series in which several great works of Arabic literature were published in annotated translations. In 1974 her own Introduction to Classical Arabic Literature appeared, the second half of which consists of translated selections.

The teaching and scholarship of Ilse Lichtenstadter were imbued with reverence for the language and culture of the Arabs as well as for the Orientalist tradition in which she and her teachers and closest colleagues had been trained. It was her conviction that a common humanity made it possible for those of one culture to understand the thoughts and feelings of members of another, even one far removed in time or place from their own.

ARON ZYSOW

University of Washington

\title{
EDWARD E. AzAR
}

PROFESSOR EDWARD E. AzAR, Director of the Center for International Development and Conflict Management at the University of Maryland (College Park) died on 18 June 1991 after a long struggle with AIDs. Born in Lebanon on 2 March 1938, Ed received his B.A. from the American University of Beirut (1960) and worked for ARAMCO for four years before traveling to the United States to pursue graduate studies in political science. He obtained his Ph.D. from Stanford University in 1969 and taught at Michigan State University (1968-1971) and the University of North Carolina (1971-1981) before joining the faculty at the University of Maryland.

An active member of the International Studies Association, in which he served as vice president in $1985, \mathrm{Ed}$ was also an editor of International Interactions (1972-1987) and associate editor of Peace Science Journal (1980-1991). Ed helped pioneer the application of quantitative analysis to international conflict issues, globally and in the Middle East. His development of the computerized Conflict and Peace Research Data Bank (COPDAB) systemized the collection and evaluation of data on international and domestic events. COPDAB contributed to the analysis of the quantity and quality of interactions among states and served as a tool for testing Ed's seminal conceptualization of protracted social conflict. Ed defined such conflict as hostile interaction within or between states that extended over long time periods with sporadic outbreaks of open warfare. The conflict had such high stakes that diplomatic or even military resolution was rarely possible. Moreover, political and social forces had strong incentives to maintain the status quo, since the benefits from the conflict were clearer 
and more immediate than the benefits from a peaceful resolution. ${ }^{1}$ Ed initially applied his conceptual framework to a wide range of conflicts: from Cyprus, Berlin, and North Ireland to China-Taiwan, Somalia-Ethiopia, and North-South Korea. By the late 1970s, he focused on the Arab-Israeli conflict, which provided a prime example of a deeply entrenched antagonism. Ed expressed skepticism about the prospects for Sadat's peace initiative to lead to an interstate accord. ${ }^{2}$ After the Egypt-Israel peace treaty was signed, he began to explore the attitudinal dimensions of social conflict in an effort to understand the perceptual shifts that were taking place in Egypt and Israel. ${ }^{3}$ During the 1980s, Ed became preoccupied with his war-torn homeland. Lebanon proved an all-too-apt example of his model of protracted social conflict. ${ }^{4}$ Nonetheless, as his health failed, he continued to address global issues. Through the Center at Maryland he examined the Argentine-British conflict over the Malvinas and the prospects for change in the Korean peninsula. Ed's concern to contribute in both scholarly and practical ways to international conflict resolution will remain an enduring legacy.

\section{ANN M. LESCH \\ Villanova University}

\section{TIBOR Halasi-Kun}

DR. TIBOR HALASI-KUN, a leading scholar on Turkic culture and a cofounder of Columbia University's Department of Near and Middle East Studies died on Saturday, 26 October 1991 of a heart attack.

$\mathrm{He}$ was born in Zagreb, Croatia, to Hungarian parents. He became multi-lingual as he grew up in Yugoslavia, Czechoslovakia, and Hungary, and also studied Greek and Latin. Specializing in Turkic studies, he obtained his doctorate at the University of Budapest. He became a professor of Hungarian, and served as director of the Hungarian Institute at the University of Ankara from 1942 to 1952.

He came to Columbia University in 1953 to teach the language, literature, and history of the Turkic peoples. He helped found Columbia's

1 Key writings include "Analysis of International Events," Peace Science Reviews 4:1 (1970); E. Azar and Joseph Ben Dak, eds., Theory and Practice of Events Research: Studies in International Actions and Interactions (1975); and "The Conflict and Peace Research Data Bank (COPDAB) Project," Journal of Conflict Resolution 23:1 (1980).

2 "Protracted Social Conflict: Theory and Practice in the Middle East," with Paul Jureidini and Ronald McLaurin, Journal of Palestine Studies 8:1 (1978).

3 "Contradictions and Skepticism: How Egyptian Studies View the Peace Process," with 'Abd al-Monein al-Mashat, International Interactions 7:4 (1981).

${ }_{4}$ Azar et al., Lebanon and the World in the 1980s (1983); Azar and John Burton, eds., Emergence of a New Lebanon (1984); Azar and John Burton, eds., Conflict Resolution: Theory and Practice (1986); Azar, Harold Saunders, and I. William Zartman, Mediation in the Middle East (1987); and Azar and C. Moon, eds., National Security in the Third World (1988). 